\title{
INDONESIA'S AIR SOVEREIGNTY ISSUES IN THE GLOBAL ERA
}

\author{
Adya Paramita Prabandari \\ Faculty of Law, Diponegoro University, Semarang \\ adyapprabandari@gmail.com
}

\begin{abstract}
A state has a government as the supreme authority that has a complete and exclusive jurisdiction over its territory. It is very important to Indonesia, with its vast territory, to preserve and uphold the state's sovereignty, particularly over its airspace. Especially in this global era, when the rapid development of technologies resulting in the end of geography era, and the world seems to be borderless. The issue discussed in this paper is Indonesia's air sovereignty issues in the global era. The things to be concerned by the Government of Indonesia on the management and protection of the state's sovereignty over the airspace in the global era are: (1) the take over of the Flight Information Region above Riau and Natuna from Singapore FIR; (2) the prevention and suppression of airspace violation incidents; and (3) the impact of Indonesia's ratification on the ASEAN Open Skies Policy to the protection of the sovereignty over Indonesia's airspace. A state's airspace is very strategic because it is the first fortress of a state, in which all foreign forces can fly in first. Therefore as a state with vast territory, the Government of Indonesia must work hard to be able to preserve and uphold the sovereignty over its territory, especially in defending the state's sovereignty over its airspace in the global era.
\end{abstract}

Keywords: Air Sovereignty; Global Era

\section{Introduction}

Based on Article 1 of the Montevideo Convention on the Rights and Duties of States 1933, an entity aspiring to be regarded as a state must meet the following qualifications: (a) possess a permanent population; (b) occupy a defined territory; (c) have an effective government over the extent of its territory; and (d) must have the capacity to engage in international relations. This Montevideo convention is the most cited source of the criteria of a state. ${ }^{1}$ While Budiardjo stated that a state is an organization in a particular region that has a highest legal authority and obeyed by his people. ${ }^{2}$ Furthermore Soehino stated that in the establishment of a state, it needed a population or people, a particular area or region, and a sovereign government. ${ }^{3}$

From several statements aforecited, it can be conclude that a state is an entity which have a permanent population live in a particular territory that has a sovereign government as the highest legal authority obeyed by the people. This government is the supreme authority, which has a

1 T. D. Grant, "Defining Statehood: The Montevideo Convention and Its Discontents." Colum. J. Transnat'l L 37, 403 (1998-1999), Accessed $\quad$ March 2017 , https://www.ilsa.org/jessup/jessup13/Defining\%20Statehood,\%20The\%20Montevideo\%20Convention\%20and\% 20its\%20Discontents.pdf.

2 M. Budiardjo, Dasar-Dasar Ilmu Politik, Edisi Revisi Cetakan Pertama (Jakarta: Gramedia Pustaka Utama, 2008), 17.

3 Soehino, Ilmu Negara, Edisi Pertama Cetakan Pertama (Yogyakarta: Liberty, 1980), 7. 
complete and exclusive sovereignty over its territory, which covers land, sea areas and airspace, with specific boundaries recognized internationally. ${ }^{4}$ On the other hand, the power and sovereignty of a state should not be against the international law and the interests of other states.

Goldstein and Pevehouse ${ }^{5}$ once said that states are separate, autonomous and equal in status, and that there is no higher authority above it. Sovereignty, as the most important norm, means that a government has the right to do whatever it wants in its own territory without any interference from other states, particularly in their internal affairs.

Conceptually, sovereignty can be divided into several categories, such as the sovereignty of God, the sovereignty of the King, the sovereignty of the people, the rule of law (the sovereignty of the law), and the sovereignty of the state. ${ }^{6}$ But categorically, it can be divided into two categories, namely the sovereignty based on the scope of implementation, and the territorial sovereignty.

The sovereignty based on the scope of implementation further divided into internal sovereignty and external sovereignty. Internal sovereignty defines as the supreme authority of a state inside its territory. Whereas external sovereignty defines as the state's ability to conduct international relations with other subjects of international law (other states, international organization etc.).

The territorial sovereignty can be defined as the authority owned by a state to exercise jurisdiction exclusively in the territory of the state in accordance with its national laws. It can be seen that there is a very strong connection between the state, the sovereignty and the territory, thus the territory of a states is a fundamental concept of the international law. States legitimately protect their territories against any unlawful action and dangerous activity. ${ }^{7}$

In regard with Indonesia, as a state with vast territory (approximately 5 million $\mathrm{km}^{2}$ ), the upholding of territorial sovereignty is very important for the persistent preservation of the territorial unity. Especially in this global era when the rapid development of communication and transportation technologies result in the end of geography era, and the world seems to be borderless.

S.S. Hadiwijoyo, Aspek Hukum Wilayah Negara Indonesia, Cetakan Pertama Edisi Pertama (Yogyakarta: Graha Ilmu, 2012); and Saru Arifin, Hukum Perbatasan Darat Antarnegara (Jakarta: Sinar Grafika, 2014), 39.

J. Goldstein \& J.C. Pevehouse, International Relations (10th ed.), (Boston: Pearson, 2014).

6 Samidjo, Ilmu Negara, (Bandung: Armico, 1986).

Michael Milde. International Air Law and ICAO (2nd ed.) (Hague, The Netherlands: Eleven International Pub, 2012). 
In this borderless global era, one part of the territory of a state that is increasingly being "vague" in its boundaries is the airspace. According to the Merriam-Webster Online Dictionary, airspace is "the space lying above the earth or above a certain area of land or water; especially: the space lying above a nation and coming under its jurisdiction". Notably for states with vast territory, it will be more difficult to preserve and uphold the state's sovereignty over its airspace. After all, the protection of the airspace is an integral part of the protection of the national territory. $^{8}$

Let alone Indonesia, which has a vast territory, lies between two continents and two oceans, and directly adjacent to ten states, it is very important to preserve and uphold the state's sovereignty, particularly over its airspace. ${ }^{9}$ And for Indonesia, the airspace is "an integral part and one of the dimensions of the area of life importance (lebensraum) of the nation and state of Indonesia". ${ }^{10}$ Thus the state of the art of this paper is the formulation of several recommendations for the Government of Indonesia related to the Indonesia's air sovereignty issues in the global era.

Based on the background described above, this paper will further discuss about the Indonesia's air sovereignty issues in the global era.

\section{Discussion}

Airspace was originally an area of the state received less attention, compared to the other two territories of a state (land and water). ${ }^{11}$ The uses of hot air balloon for transportation, and the invention of aircraft by the Wright Brothers, plus the development of air transportation, bring up the need to regulate the state's sovereignty over its airspace.

But actually centuries ago, a Roman adagium stated "Cujus est solum, ejus est usque ad coelum" which can be interpreted that whoever possesses the land (whether individual or state), then the ownership rights applies not only to what is on the ground, but also to what is in the ground and above the ground indefinitely (ad infinitum/up to the sky). ${ }^{12}$

8 Ibid.

9 Ludiro Madu, dkk. (Editor), Mengelola Perbatasan Indonesia di Dunia Tanpa Batas (Yogyakarta: Graha Ilmu, 2010), 28.

10 Danang Risdiarto, "Penegakan Hukum terhadap Pelanggaran Wilayah Udara Yurisdiksi Indonesia oleh Pesawat Terbang Asing Tidak Terjadwal", Jurnal Rechtsvinding 5, No. 1 (2016): 73.

11 Agus Pramono, "Air Sovereignty and No-Fly Zones", Diponegoro Law Review 01, No. 01(2016): 100.

12 Yehuda Abramovitch, "The Maxim 'Cujus Est Solum Ejus Usque ad Coelum' As Applied in Aviation," McGill Law Journal 8, (1962): 247, Accessed Monday October 12, 2015, http://www.lawjournal.mcgill.ca/userfiles/other/8509457-abramovitch.pdf; Priyatna Abdurrasyid, Kedaulatan Negara di Ruang Udara (Jakarta: Fikahati Aneska, 2003), xxiii; and Chappy Hakim, Tanah Air dan Udaraku 
The first international treaty regulate the state's sovereignty over its airspace is the Convention relating to the Regulation of Aerial Navigation held in Paris October 13, 1919 (known as Paris Convention 1919). Article 1 of the Convention stated that: "The High Contracting Parties recognise that every Power has complete and exclusive sovereignty over the airspace above its territory". Furthermore it explains that the territory of a state consists of the national territory (both at the mother country and of the colonies), and also the territorial waters adjacent thereto.

Regulation on the sovereignty of airspace originated on international customary law comes from the UK since the release of the Aerial Navigation Act of 1911 which provides that the UK has a full and complete sovereignty over the airspace above its territory, so that the UK has the absolute right to supervise all flight, aircraft both civilian and military aircraft. After the UK issued the Aerial Navigation Act of 1911, then various European states also followed to issue regulations in each state, thus creating a customary international law concerning the full and complete sovereignty over a state's airspace.

The Paris Convention 1919 was then replaced by the Convention on International Civil Aviation held on December 7, 1944 (known as the Chicago Convention 1944). The regulation on the state's sovereignty over its airspace is re-stated and strengthened in Article 1, which states that: "The Contracting States recognize that every State has complete and exclusive sovereignty over the airspace above its territory". Further explained in the Second Article that the definition of the territory of a State in the Convention is consists of the land areas and territorial waters adjacent thereto.

The rules regarding the state's sovereignty over its airspace in the Chicago Convention 1944 is what continues to be used and maintained until today in the international community. Nevertheless, the "legal status of airspace in international law develops very rapidly based on evolving states' practice."13

In respect to the state's sovereignty over its airspace, we should also consider about its limits or boundaries. The horizontal boundary of a state's sovereignty over its airspace is following the state's land and water boundaries. For example, Indonesia's sovereignty of its airspace over the land areas in Papua is based on the Agreement between Indonesia and Australia concerning Certain Boundaries between Indonesia and Papua New Guinea, signed at

Indonesia (Jakarta: Red \& White Publishing, 2015), 24.

13 Adi Kusumaningrum, "The Legal Analysis of "Teori Kedaulatan Nusantara" towards the New Conception of Indonesia Airspace Sovereignty”, Indonesian Journal of International Law 14, No. 4 (2017): 514. 
Jakarta on February 12, 1973. And for the sea boundaries on the territorial waters is following Article 2 Paragraph 2 and Article 3 of the United Nations Convention on the Law of the Sea 1958, which is not more than 12 nautical miles from the baselines defined in the Convention. Meanwhile on the vertical boundaries, until now there is no international convention governing the vertical boundaries of the airspace. But in the international air law practice, the state's sovereignty over its airspace vertically is determined on the ability of the state concerned to preserve and uphold its sovereignty.

Aside from the rules of international law as described previously, there are also Indonesian national regulations regarding the air sovereignty. The territory of Indonesia has been set out clearly in the 1945 Constitution after amendments (known as the 1945 Constitution of the Republic of Indonesia) Article 25A, that said: "the Unitary State of the Republic of Indonesia is an archipelagic state, the boundaries and rights of whose territory shall be established by law", which further regulated in the Act Number 43 Year 2008 on the Territory of the State. In Article 4 of the Act Number 43 Year 2008 stated that: "The territory of the State covering land, waters, seabed, and the ground beneath and the airspace above it, including all sources of wealth contained therein".

Whereas in term of sovereignty over its territory can be seen implicitly in the Aims of the Republic of Indonesia in the Fourth Paragraph of the Preamble of the Constitution which said “... to form a Government of the State of Indonesia which shall protect the whole Indonesian nation and the rest native land of Indonesia, ...". It can be interpreted that Indonesia has a complete and exclusive sovereignty of the territory of the State.

Hereinafter, related to the regulation and protection of the Indonesian airspace and aviation, the Government first published the Act Number 83 Year 1958 on Aviation. Unfortunately there is no specific article that clearly regulating the Indonesia's sovereignty over the airspace. But the sovereignty of the airspace can be inferred from the provisions of this Act, for example in Article 1 (c) concerning the region for the purpose of flight, or in Article 8 concerning the commercial airfreight. ${ }^{14}$

Some years later, the Government issued the Act Number 15 Year 1992 on Aviation, as a replacement of the Act Number 83 Year 1958 on Aviation. The new Act has been set up

14 H.K. Martono and Amad Sudiro, Hukum Udara Nasional dan Internasional Publik (Public International and National Air Law) (Jakarta: RajaGrafindo Persada, 2012). 
specifically and clearly about the sovereignty of the airspace in Chapter III, Article 4 to Article 6. In Article 4 stated that the Republic of Indonesia has a full and complete sovereignty over its airspace, which authority and responsibility on the arrangements for the state's defense and security, the aviation, and national economies conducted by the Government. Thus based on this authority, the Government then establish a prohibited airspace area, the so-called no-fly zone, for the sake of defense and aviation safety. In this no-fly zone, both Indonesian and foreign aircrafts are prohibited to fly over, and for those who violate the no-fly zone will be forced to land at the nearest air base or airport in the territory of Indonesia by the Indonesia Air Force. This rule can be found in Article 6 and Article 53 of the Act Number 15 Year 1992.

The Government then replaced the Act Number 15 Year 1992 on Aviation with the Act Number 1 Year 2009 on the Civil Aviation (known as Civil Aviation Act/CAA). This new act is drafted refers also to the Chicago Convention 1944, and is a renewal and replacement of the previous act with regard to the development of the aviation world in Indonesia, thus this act consists of hundreds of articles that are very comprehensive in regulating various things in the Indonesian aviation.

As to the state's sovereignty over its airspace is also clearly regulated in this act, specifically in Chapter IV, Article 5 to Article 9. Article 5 stated that the Republic of Indonesia have a full and exclusive sovereignty over its airspace. Thus the Government have the authority and responsibility on the management of the airspace for the sake of aviation, national economies, state's defense and security, social and culture, and also the air environment, as regulated in Article 6. This act also regulates the Government's right to establish a prohibited airspace area and restricted airspace area (Article 7 (1)). Further stated in Article 7 (2) and (3) that both Indonesian and foreign aircrafts are prohibited to fly in the prohibited airspace area, and this no-fly restriction is permanent and thorough. Meanwhile, only the state aircrafts is allowed to fly in the restricted airspace area (Article 7 (4)). For those who violate the rules will be given a warning to leave the no-fly zone as soon as possible by the air traffic personnel, and if it does not heed the warning, then it will be forced to leave the no-fly zone or to land at particular air base or airport in the territory of Indonesia (Article 8).

One of the Aims of the Republic of Indonesia in the Fourth Paragraph of the Preamble of the Constitution said “... to form a Government of the State of Indonesia which shall protect the whole Indonesian nation and the rest native land of Indonesia, ...”. It can be interpreted that Indonesia has a complete and exclusive sovereignty of the territory of the State. But 
unfortunately, in the 1945 Constitution does not mention explicitly on the issue of airspace. For example in Article 33 of the 1945 Constitution of the State of the Republic of Indonesia which only mentions the area of the land and water only, and does not mention at all about the air territory. Whereas a country has a complete sovereignty covering three dimensions, namely the dimensions of terrestrial, marine and airspace that is a "one political unit" that cannot be separated.

It is unfortunate that the Indonesia's airspace that has a strategic position in the context of national defense and security, economy, and in global air transport has not been explicitly incorporated in the state's constitution. As a result, the management and protection of the Indonesia's airspace has no constitutional basis. This raises various issues and problems to be concerned by the Government as the authority who responsible on the management and protection of the airspace, namely:

a. On the Flight Information Region

The sovereignty of airspace issue cannot be separated from the management of the air traffic and navigation system at the airspace above the territorial area, known as Flight Information Region (FIR). Based on the Supplement Aeronautical Information Publication (Letter of the Directorate General of Civil Aviation Number 02/05, April 14, 2015), Indonesia has two FIRs, namely the Jakarta FIR and the Ujung Pandang FIR (now the Makassar FIR) since May 12, 2005. But the airspace above Riau and Natuna is under the management of Singapore FIR. Historically this arrangement is the legacy of the British as the occupiers of Singapore. Based on the decisions made in the ICAO meeting in Dublin, Ireland, on March 1946, the British Government was appointed to manage the area, which was then headed over to Singapore at the time of independence in 1963. Indonesia actually has always been making every effort to take over the management of FIR over this region, but until now has not succeeded because Indonesia is considered not to have the readiness of infrastructure and human resources in accordance with the ICAO standards. ${ }^{15}$

b. On the airspace violation/aerial intrusion

Airspace violation or aerial intrusion is a condition in which there is foreign aircrafts (whether civil or state aircrafts) entering the airspace of a state without prior permission. ${ }^{16}$ The

15 E.A. Retadutari, "Soal Pengambilalihan FIR dari Singapura, KSAU: Kami Sudah Siap,” Detik.com. Accessed March 15, 2017, https://news.detik.com/berita/3415359/soal-pengambilalihan-fir-dari-singapura-ksau-kamisudah-siap?_ga=1.219569369.1778593858.1447200686

16 Handar Subhandi Bakhtiar, Syamsuddin Muhammad Noor, and Abdul Maasba Magassing, "Violation of the Sovereignty of Indonesia Airspace by Foreign Aircraft", International Journal of Advanced Research 5, No.2 
incident could be deliberate action (eg. black flight with certain objectives), or unintentionally action (eg. lost aircraft or aircraft in distress). Such violations can occur to any state, as well as in Indonesia as an archipelagic state with vast territories. Several cases of Indonesian airspace violation have been recorded. The first violation occurred on July 2, 2003 when five F-18 Hornet US military aircrafts crossed Bawean Island without permission. Then in June 2011, a giant transport plane, the $\mathrm{C} 17$ Globe Master transport aircraft entered Indonesian territory without permission through Pekanbaru, Riau. On November 29, 2012, a civilian aircraft carrying the deputy Prime Minister of Papua New Guinea was tightly escorted by the TNI-AU military aircrafts for 37 minutes because it passed without permission. ${ }^{17}$ And not to forget, the incident when two Hercules C-130 aircrafts of the Tentara Udara Diraja Malaysia is entering the airspace over Natuna without any permission, which then both Malaysian aircraft was driven away by two F-16 Fighting Falcon aircrafts of the Indonesian Air Force. ${ }^{18}$ These cases are examples of airspace violation cases in which the aircrafts was only escorted to exit Indonesian airspace. But there are also a number of cases where the aircrafts was requested or forced to disembark and land at the nearest airport in Indonesian territory (known as forced down), such as: (1) on September 30, 2012 US Cessna 208 pilot Michael A. Boyd crossed without permission in Indonesian airspace, then was forced to land at Sepinggan airport in Balikpapan, East Kalimantan; ${ }^{19}$ (2) A foreign aircraft manned by two pilots from Australia flew without permission in Manado and forced down and land at the Sam Ratulangi Air Force Base, Manado (October 22, 2014); ${ }^{20}$ and (3) A Singapore military aircraft was forced to land at Supadio Airport, Pontianak, while crossing the Kalimantan region (October 28, 2014). ${ }^{21}$

\section{c. On the ASEAN Open Skies Policy}

Liberalization of air transport has experienced significant developments, especially in terms of market access, specifically at the regional and sub-regional levels since the ICAO's $4^{\text {th }}$

(2017): 2107-2113.

17 Baiq Setiani, "Konsep Kedaulatan Negara di Ruang Udara dan Upaya Penegakan Pelanggaran Kedaulatan oleh Pesawat Udara Asing”, Jurnal Konstitusi 14, No. 3 (2017): 500 -501.

18 Anggi Kusumadewi, "TNI AU: Malaysia-RI Harus Tentukan Batas Wilayah Udara Natuna," CNN Indonesia, Accessed March 15, 2017, http://www.cnnindonesia.com/nasional/20160629100551-20-141734/tni-aumalaysia-ri-harus-tentukan-batas-wilayah-udara-natuna/.

19 Edna C. Pattisina, "Sukhoi Paksa Pesawat AS Mendarat," Accessed September 10, 2019, https://tekno.kompas.com/read/2012/10/01/16133041/sukhoi.paksa.pesawat.as.mendarat.

20 Indra Wijaya, "Kronologi Sukhoi Paksa Pesawat Australia Mendarat," Accessed September 10, 2019, https://nasional.tempo.co/read/616598/kronologi-sukhoi-paksa-pesawat-australia-mendarat.

21 "Pesawat Singapura Pelanggar Ruang Udara Dilepas TNI AU", Accessed September 9, 2019 https://www.tni.mil.id/view-67421-pesawat-singapura-pelanggar-ruang-udara-dilepas-tni-au.html. 
World Wide Air Transport Conference. ${ }^{22}$ The ASEAN Open Skies Policy (or also known as the ASEAN Single Aviation Market) is a policy that aims to increase regional and domestic connectivity, integrate production networks, and enhance regional trade by allowing airlines from all ten ASEAN member states to fly freely throughout the region via the liberalization of air services under a single and unified air transport market. This policy is a form of globalization in the air transportation field, where later be established a central agency control of the ASEAN airspace (Air Traffic Flow Management/ATFM) that will be in force regionally. As a member of ASEAN, which already ratified the policy, Indonesia must be ready to compete with other ASEAN member states in providing the best services, infrastructures and facilities at the airports and also the airlines. On the other side, this policy resulting in the openness of the airspace of Indonesia, and thus will bring impact to the protection of the sovereignty over Indonesia's airspace. This will also have implications for the exclusive economic rights to serve air transportation services in a state that can only be served by the national airline of that state (the principle of cabotage). ${ }^{23}$

Those three issues as mentioned above are interrelated and cannot be separated when discussing the sovereignty of Indonesian airspace. The first issue on the take over of the FIR above Riau and Natuna Islands is the first issue that must be immediately followed up and resolved by the Government of Indonesia. As long as we have not taken over the control of the FIR above Riau and Natuna Islands, we have not yet fully mastered our airspace. And therefore will disadvantage us both in terms of state security and economic terms. The disadvantage in terms of state security is closely related to the second issue on the airspace violation/aerial intrusion. If Indonesia has been able to fully control the FIR over the entire territory of the state, it will be easier for the Air Force, as the authority of the subjacent state, to intercept or to force down a foreign aircraft that entering Indonesia airspace without prior permission, in terms of self-defence. ${ }^{24}$ Thus the Indonesia Air Force is able to protect and uphold the sovereignty of the Indonesia airspace, as well as the national defence and security from airspace violation/aerial intrusion. Furthermore regarding the third issue on Indonesia participation on the ASEAN Open Skies Policy, the takeover of control over FIR above Riau and Natuna will greatly benefit

22 Adi Kusumaningrum, "Pengaturan Safeguards Sektor Angkutan Udara ASEAN di Era Liberalisasi Jasa", Jurnal Bina Mulia Hukum 1, No. 2 (2017): 190.

23 Endang Puji Lestari, "Rekonsepsi Hak Penguasaan Negara atas Wilayah Udara di Tengah Kebijakan Liberalisasi Penerbangan," Jurnal Rechtsvinding 4, No. 2 (2015): 341-342.

24 Sefriani, "Pelanggaran Ruang Udara oleh Pesawat Asing menurut Hukum Internasional dan Hukum Nasional Indonesia,” Jurnal Hukum Ius Quia Iustum 22, No. 4 (2015): 538-565. 
Indonesia economically, in relation to the Route Air Navigation Services/RANS Charges that charged on aircrafts that fly across the FIR above Riau and Natuna Islands.

\section{Conclusions}

The recognition of state's sovereignty over its airspace does not mean closing the national airspace from flights or aircrafts from other states. But it is very important for the persistent preservation of the territorial unity. Especially in this global era, where the rapid development of communication and transportation technologies result in the end of geography era, and lead this world be like borderless.

In this borderless global era, one part of the territory of a state that is increasingly being "vague" in its boundaries is the airspace. Notably for states with vast territory like Indonesia, it will be more difficult to preserve and uphold the state's sovereignty over its airspace.

A state's airspace is very strategic because in term of sovereignty, the airspace is the first fortress of a state, in which all foreign forces can fly in first, thus the airspace becomes very vulnerable. But on the other side, the airspace can be used as a bargaining power in bilateral or multilateral air transport agreements and has economic value.

Therefore as a state with vast territory, the Government of the Republic of Indonesia must work hard to be able to preserve and uphold the sovereignty over its territory, especially in defending the state's sovereignty over its airspace in the global era.

But there are some issues to be concerned by the Government as the authority who is responsible on the management and protection of the airspace, regarding Indonesia's sovereignty over the airspace in the global era. First, is the takeover of the Flight Information Region above Riau and Natuna from Singapore FIR. Second, is the prevention and suppression of airspace violation or aerial intrusion incidents. And lastly is on the impact of Indonesia's ratification on the ASEAN Open Skies Policy to the protection of the sovereignty over Indonesia's airspace.

In order to overcome the various issues mentioned above, there are several recommendations as follows; in order to provide a constitutional basis on the management and protection of airspace of the Republic of Indonesia, it should be added explicitly in Article 33 Paragraph 3 of the 1945 Constitution regarding "the Indonesian airspace", if there is an amendment of the 1945 Constitution in the future. This is important to do so in order to provide a strong constitutional basis for Indonesia national interest regarding the management and protection of airspace sovereignty both in the security and economic fields, fixing and updating 
aviation infrastructure, such as airport facilities and especially air navigation systems and Air Traffic Control technology in accordance with the standards set by ICAO, in terms of diplomacy in foreign relations, the Minister of Foreign Affairs should re-negotiated with Singapore on the FIR boundary between Indonesia and Singapore, and requested that the management of FIR in airspace over Riau and Natuna Islands be handed over to Indonesia as Indonesia has been able to manage it accordingly with standards set by ICAO, to deregulate the Aviation Law in terms of granting special powers to the Indonesian Air Force in terms of sanctions for violators of Indonesian air sovereignty, the Government should build new air bases, especially in the outer points of the Indonesian territory so that the supervision and guarding of Indonesian airspace can be done more optimally and thoroughly. The addition of a number of advanced air squadrons and radar by TNI AU is also needed to strengthen air security monitoring and defense system in order to maintain sovereignty in the airspace of NKRI.

\section{References}

Abdurrasyid, P. Kedaulatan Negara di Ruang Udara. Jakarta: Fikahati Aneska, 2003.

Abramovitch, Y. "The Maxim 'Cujus Est Solum Ejus Usque ad Coelum' As Applied in Aviation." McCill Law Journal, 8 http://www.lawjournal.mcgill.ca/userfiles/other/8509457-abramovitch.pdf.

Arifin, S. Hukum Perbatasan Darat Antar Negara. Jakarta: Sinar Grafika, 2014.

Bakhtiar, H.S., Noor, S.M., and Magassing, A.M.. "Violation of the Sovereignty of Indonesia Airspace by Foreign Aircraft", International Journal of Advanced Research 5, No. 2 (2017): 2107-2113.

Budiardjo, Miriam. Dasar-Dasar Ilmu Politik. First Edition. Jakarta: Gramedia Pustaka Utama, 2008.

Convention on International Civil Aviation (Chicago Convention 1944).

Convention relating to the Regulation of Aerial Navigation (Paris Convention 1919).

Goldstein, J., \& Pevehouse, J. C. International Relations (10th ed.). Boston: Pearson, 2014.

Grant, T. D. Defining Statehood: The Montevideo Convention and Its Discontents. Colum. J. Transnat'l L 37, 403 (1998-1999). Accessed March 15, 2017. https://www.ilsa.org/jessup/jessup13/Defining\%20Statehood,\%20The\%20Montevideo\% 20Convention\%20and\%20its\%20Discontents.pdf. 
Hadiwijoyo, S. S. Aspek Hukum Wilayah Negara Indonesia (1st ed.). Yogyakarta: Graha Ilmu, 2012.

Hakim, C. Tanah Air dan Udaraku Indonesia. Jakarta: Red \& White Publishing, 2015.

Kusumadewi, A. “TNI AU: Malaysia-RI Harus Tentukan Batas Wilayah Udara Natuna." CNN Indonesia. Last Modified June 29, 2016. Accessed March 15, 2017. http://www.cnnindonesia.com/nasional/20160629100551-20-141734/tni-au-malaysia-riharus-tentukan-batas-wilayah-udara-natuna/.

Kusumaningrum, A. "The Legal Analysis of "Teori Kedaulatan Nusantara" towards the New Conception of Indonesia Airspace Sovereignty”. Indonesian Journal of International Law 14, No. 4 (2017).

- "Pengaturan Safeguards Sektor Angkutan Udara ASEAN di Era Liberalisasi Jasa". Jurnal Bina Mulia Hukum 1, No. 2 (2017).

Lestari, E. P. "Rekonsepsi Hak Penguasaan Negara atas Wilayah Udara di Tengah Kebijakan Liberalisasi Penerbangan". Jurnal Rechtsvinding 4, No. 2 (2015).Madu, L., et al. Mengelola Perbatasan Indonesia di Dunia Tanpa Batas. Yogyakarta: Graha Ilmu, 2010.

Martono, H.K. \& Sudiro, A. Hukum Udara Nasional dan Internasional Publik (Public International and National Air Law). Jakarta: RajaGrafindo Persada, 2012.

Merriam-Webster Online Dictionary. Last modified January 19, 2015. http://www.merriamwebster.com/dictionary/airspace.

Milde, M. International Air Law and ICAO (2nd ed.). Hague, The Netherlands: Eleven International Pub., 2012.

Pattisina, E. C. "Sukhoi Paksa Pesawat AS Mendarat." Last modified October 1, 2012. Accessed September 10 , 2019. https://tekno.kompas.com/read/2012/10/01/16133041/sukhoi.paksa.pesawat.as.mendarat.

Pramono, A. “Air Sovereignty and No-Fly Zones”, Diponegoro Law Review 01, No. 01 (2016)

Retadutari, E. A. "Soal Pengambilalihan FIR dari Singapura, KSAU: Kami Sudah Siap." Detik.com. Last modified February 7, 2017. Accessed March 15, 2017. https://news.detik.com/berita/3415359/soal-pengambilalihan-fir-dari-singapura-ksaukami-sudah-siap?_ga=1.219569369.1778593858.1447200686.

Risdiarto, D. "Penegakan Hukum terhadap Pelanggaran Wilayah Udara Yurisdiksi Indonesia oleh Pesawat Terbang Asing Tidak Terjadwal”. Jurnal Rechtsvinding 5, No. 1 (2016).

Samidjo. Ilmu Negara. Bandung: Armico, 1986. 
Sefriani, S. "Pelanggaran Ruang Udara oleh Pesawat Asing menurut Huum Internasional dan Hukum Nasional Indonesia”. Jurnal Hukum Ius Quia Iustum 22, No. 4 (2015).

Setiani, B. "Konsep Kedaulatan Negara di Ruang Udara dan Upaya Penegakan Pelanggaran Kedaulatan oleh Pesawat Udara Asing”. Jurnal Konstitusi 14, No. 3 (2017).

The 1945 Constitution of the Republic of Indonesia.

The Act Number 1 Year 2009 on Aviation.

The Act Number 15 Year 1992 on Aviation.

The Act Number 43 Year 2008 on the Territory of the State.

The Act Number 83 Year 1958 on Aviation.

TNI. (2014, October 30).’Pesawat Singapura Pelanggar Ruang Udara Dilepas TNI AU.” Last modified October 30, 2014. Accessed September 9, 2019. https://www.tni.mil.id/view67421-pesawat-singapura-pelanggar-ruang-udara-dilepas-tni-au.html.

Wijaya, I. "Kronologi Sukhoi Paksa Pesawat Australia Mendarat." Last modified October 3, 2014. Accessed September 10, 2019. https://nasional.tempo.co/read/616598/kronologisukhoi-paksa-pesawat-australia-mendarat. 